\title{
マグネシウム単結晶における疲労き裂進展機構*1
}

\author{
1熊本大学工学部知能生産システム工学科 \\ 2熊本大学大学院自然科学研究科 \\ J. Japan Inst. Metals, Vol. 67, No. 5 (2003), pp. 247-251 \\ (C) 2003 The Japan Institute of Metals
}

安藤 新二1 猿渡功 -2 ,*2 堀 隆 之 2 ,*3 $\quad$ 頓田 英 機1

\section{Fatigue Crack Propagation Behavior in Magnesium Single Crystals}

\author{
Shinji Ando ${ }^{1}$, Kouichi Saruwatari ${ }^{2, * 2}$, Takayuki Hori ${ }^{2, * 3}$ and Hideki Tonda ${ }^{1}$ \\ ${ }_{1}^{1}$ Department of Mechanical Engineering and Materials Science, Faculty of Engineering, Kumamoto University, Kumamoto 860-8555 \\ ${ }^{2}$ Graduate School of Science and Technology, Kumamoto Univerisity, Kumamoto 860-8555
}

The fatigue crack growth behavior of magnesium single crystal was investigated in order to clarify the orientation dependence of fatigue crack propagation mechanisms. Four types of compact specimens with respect to active slip and twin systems at a crack tip were prepared from magnesium single crystals grown by the Bridgman technique. In the case of the plane and the direction of notch are $(1 \overline{2} 10)$ and $[10 \overline{1} 0]$ respectively, fatigue crack propagated parallel with the notch, while the fatigue crack propagated inclined 30 degrees from the initial notch in the case of (1010) [12 10$]$ notch. In both cases, the growth directions of their cracks were $[10 \overline{1} 0]$ and the configurations of their crack surfaces were similar. From TEM observation, it was found that pyramidal slip systems with $(\boldsymbol{c}+\boldsymbol{a})$ Burgers vector were activated at the crack tip. From these results, a fatigue crack propagation mechanism was proposed. In the case of $(1 \overline{2} 10)[0001]$ notch, fatigue crack propagated to [0001] at low stress intensity factor range, $\Delta K$ and the growth direction was deflected in parallel to basal plane at high $\Delta K$. In the case of $(0001)[1 \overline{2} 10]$ notch, fatigue crack propagated along the basal plane being accompanied by $\{10 \overline{1} 2\}$ twins. The fatigue crack growth rate of the specimen with $(10 \overline{1} 0)[1 \overline{2} 10]$ notch was the lowest in the four type specimens. It is concluded that the fatigue crack propagation behavior of magnesium changes greatly with crystallographic geometry of notch.

(Received December 9, 2002; Accepted March 19, 2003)

Keywords: magnesium, single crystal, fatigue crack, twin, basal slip, stress intensity factor, $d a / d N$

\section{1. 緒言}

金属の疲労破壊過程において，損傷許容設計の観点では， き裂進展過程が重要である11)。このき裂進展過程について, fcc p bcc 金属では多くの研究がなされているが，マグネシ ウムのような hcp 金属についての報告は少なく，その機構 については十分に知られていない。これまで筆者らは, チタ ンに抢ける疲労き裂伝播機構を単結晶 $\mathrm{CT}$ 試験片を用いて調 査した結果 ${ }^{2-4)}$, 結晶学的方位の違いによって疲労き裂伝播 挙動が大きく異なることを報告している. その場合, き裂先 端での塑性変形機構がき裂進展に強く影響するが，チタンの 優先すべり系は柱面すべりであるのに対し，マグネシウムは 底面すべりであることから, 両者のき裂進展機構は大きく異 なると予想される. 前報5)では, 純マグネシウム多結晶試料 の疲労き裂伝播挙動を調査した結果, 結晶粒の凝固方向とき

*1 2002 年 11 月 2 日日本金属学会秋期大会において発表

*2 熊本大学大学院生 (Graduate Student, Kumamoto University)

*3 熊本大学大学院生, 現在 : 三井金属鉱業陎) (Graduate Student, Kumamoto University, Present adderss: Mitsui Mining and Smelting Co., Ltd.)
裂進展方向に強い依存性があった．そこでき裂進展機構の方 位依存性を詳しく調査するために，切欠面㧍よび方向が異な る 4 種類の単結晶試験片を作製し, 疲労き裂進展試験を行 った。

\section{2. 実 験 方 法}

純度 $99.9 \%$ 純マグネシウムインゴットから改良型 Bridgman 法により単結晶を育成し, Fig. 1 に示す 4 種類の $\mathrm{CT}$ 試験片を作製した．各試験片の切欠面および方向は，き 裂先端で活動するすべり系や双晶系を考慮して選択した．A および B 試料は底面すべりが活動できずに非底面すべりが 活動する方位, $\mathrm{D}$ 試料では底面すべりが活動できる方位, F 試料は $\{10 \overline{1} 2\}$ 双晶が起こりうる方位とした．試験片には温 度範囲 $673 \mathrm{~K} \sim 523 \mathrm{~K}, 1$ サイクル $21.6 \mathrm{ks}$ の熱サイクル焼鈍 を 8 サイクル施した.これらを電気油圧式サーボ試験機を 用いて, 室温大気中, 応力比 0.1 , 荷重繰り返し周波数 10 $\mathrm{Hz}$ で疲労き裂進展試験を行った. 試験は, 切欠から疲労き 裂を発生させた後, 下限界応力拡大係数範囲 $\Delta K_{\mathrm{th}}$ 付近まで 荷重を徐々に減少させ, その間に, 一定の応力拡大係数範囲 $\Delta K$ での疲労き裂伝播速度 $d a / d N$ を, 試験片表面でのき裂 
長さより求めた。

\section{3. 結果}

Fig. 2 に A および B 試料の疲労き裂進展経路を示す． A 試料では切欠面に平行にき裂が伝播し，B 試料では切欠に対 し $30^{\circ}$ 傾いた $(1 \overline{2} 10)$ に沿ってジグザグに伝播した。すなわち

(a)

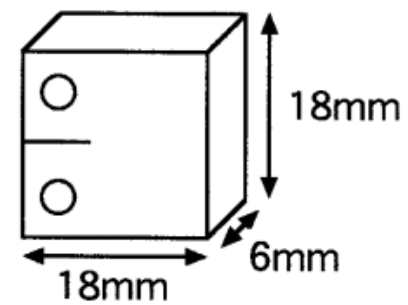

(b) A-specimen

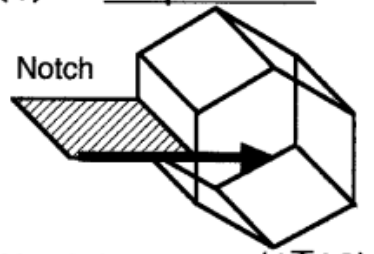

Notch Plane

:(1210)

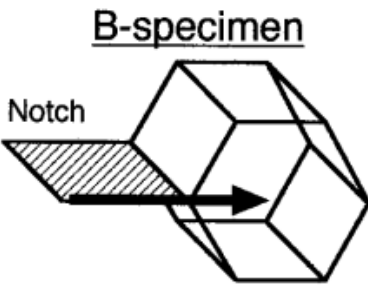

Notch Direction : [1010]

D-specimen

Notch Plane : (10T0)

Notch Direction : [1210]

F-specimen

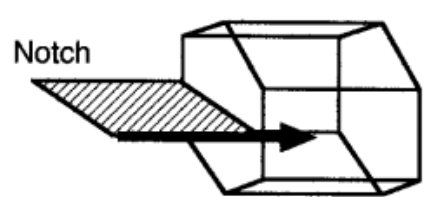

Notch Plane

: (1210)

Notch Direction : [0001]

Notr

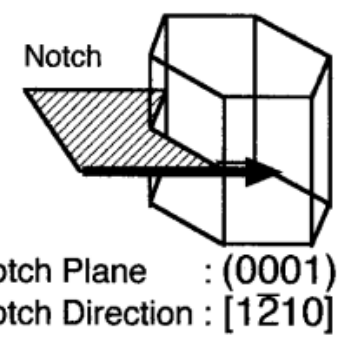

Fig. 1 (a) Dimension of CT specimen and (b) notch orientationsof specimens.
切欠が底面に垂直で，き裂伝播方向が底面に平行の場合は， き裂は $\{11 \overline{2} 0\}$ 上を〈1 100$\rangle に$ 伝播するといえる. Fig. 3 に A 試料の疲労破面を示す. $\Delta K \simeq 0.9 \mathrm{MPam}^{1 / 2}$ では，き裂伝播 方向に平行に規則的な筋模様が生じ， $\Delta K \simeq 1.3 \mathrm{MPam}^{1 / 2}$ で は，これに加え，き裂伝播方向に対し約 $43^{\circ}$ 傾いた平行な筋 模様が形成されている.このような筋模様が形成されること から，き裂先端で何らかの塑性変形機構を伴ったき裂進展機 構であると推察される。これらの破面形態は B 試料でも同 様であり，両試料には同一のき裂進展機構が働いていると考 えられる。

そこで，A 試料の破面直下の転位構造を TEM 写真を Fig. 4 に示す. 試料は $\Delta K \simeq 1.5 \mathrm{MPam}^{1 / 2}$ の領域から切り出 したもので，薄膜面はき裂進展方向に垂直である．図中には 疲労破面である $(1 \overline{2} 10)$ のトレースを示した $\boldsymbol{g} \cdot \boldsymbol{b}=0$ の関係 より, 0002 回折では $\boldsymbol{c}$ と $(\boldsymbol{c}+\boldsymbol{a}), 11 \overline{2} 0$ 回折では $\boldsymbol{a}$ と $(\boldsymbol{c}+$ $\boldsymbol{a})$ のバーガースベクトルを持つ転位が観察されることにな る.これより，底面に平行な転位は，いずれの回折条件でも 見えることから $(\boldsymbol{c}+\boldsymbol{a})$ 転位であり， $(\boldsymbol{c}+\boldsymbol{a})$ 錐面すべりが活 動していることがわかる. また Fig. 4(b)から，Fig. 4(a)で 観察される $(\boldsymbol{c}+\boldsymbol{a})$ 転位以外にも, 多数の a 転位も生じてい ることがわかる。

次 D 試料に打けるき裂伝播経路を Fig. 5 に示す。前報5) に颃いて，この切欠方位では初期き裂を導入する段階で, $\Delta K=0.5 \mathrm{MPam}^{1 / 2}$ まで徐々に荷重を増加させた場合, 切欠 先端と荷重を負荷するためのピン穴の間で底面すべりが生じ ることにより切欠部が開口するだけで, 疲労き裂は生じなか った。しかし今回, 試験開始時に一度に $\Delta K=0.8 \mathrm{MPam}^{1 / 2}$ の荷重をかけた場合, 底面すべりをほとんど生じることなく, Fig. 5 に示すように, 切欠に平行に沿って疲労き裂が発生し た.しかし荷重を徐々に増加させ， $\Delta K=0.9 \mathrm{MPam}^{1 / 2}$ にな ると切欠先端から別のき裂が発生し, 最終的に切欠に対し $90^{\circ}$ 傾いた底面に沿ってき裂が伝播した。このように D 試料 の疲労き裂伝播挙動は， $\Delta K$ に大きく依存することがわかっ
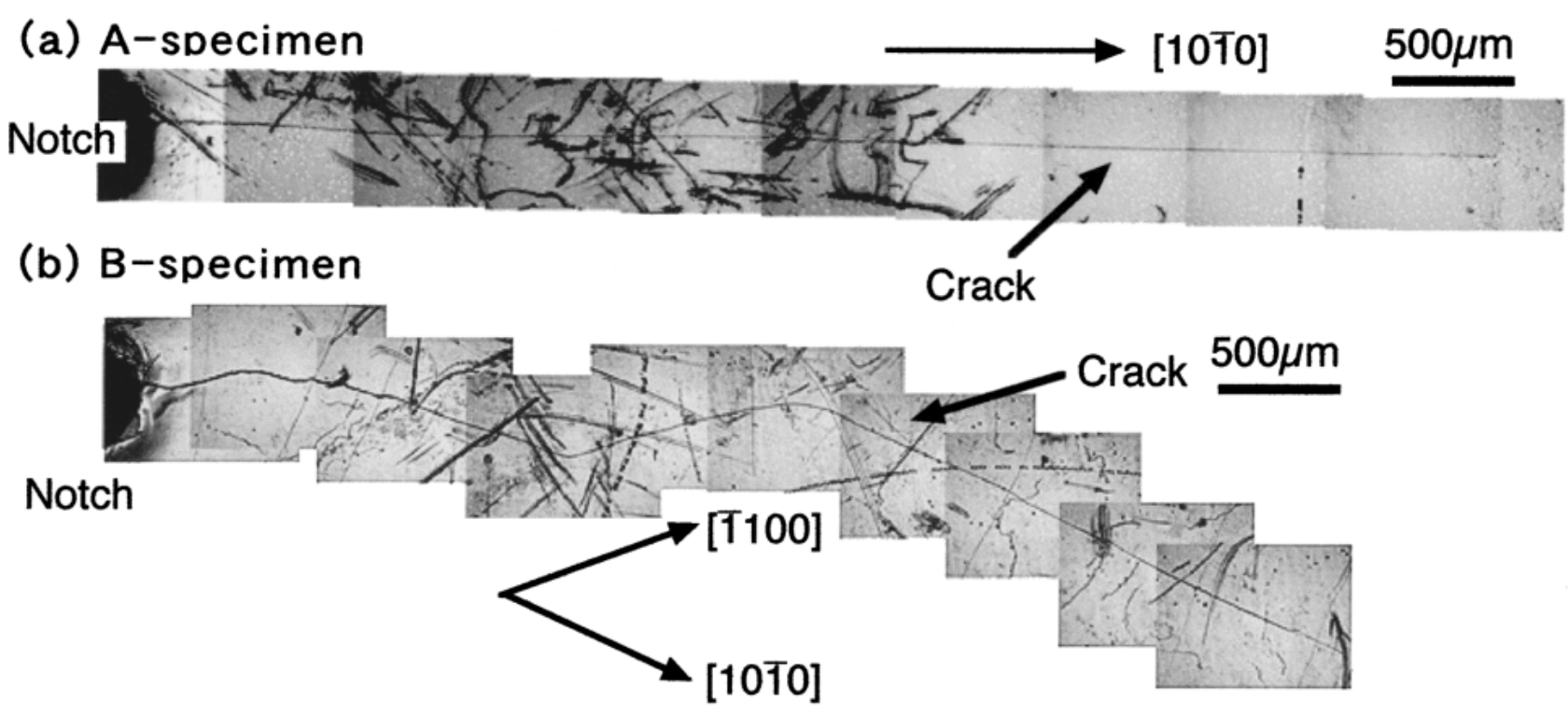

Fig. 2 Crack profiles of (a) A- and (b) B-specimens. 
(a) $\Delta K=0.9 \mathrm{MPam}^{1 / 2}$

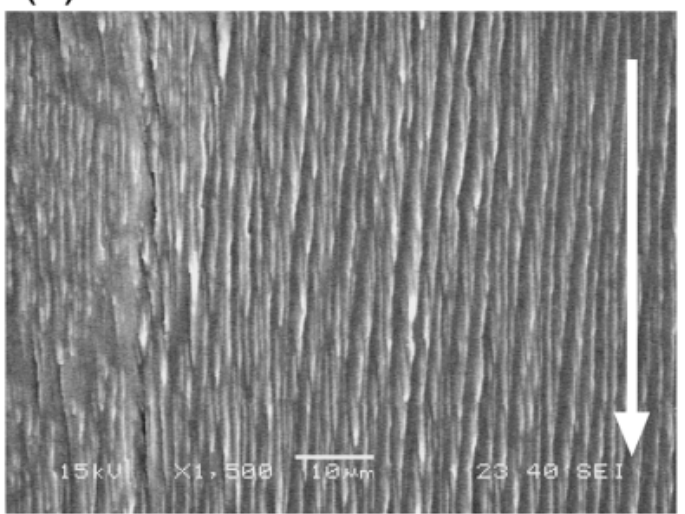

$\overline{10 \mu \mathrm{m}}$ (b) $\Delta K=1.5 \mathrm{MPam}^{1 / 2}$

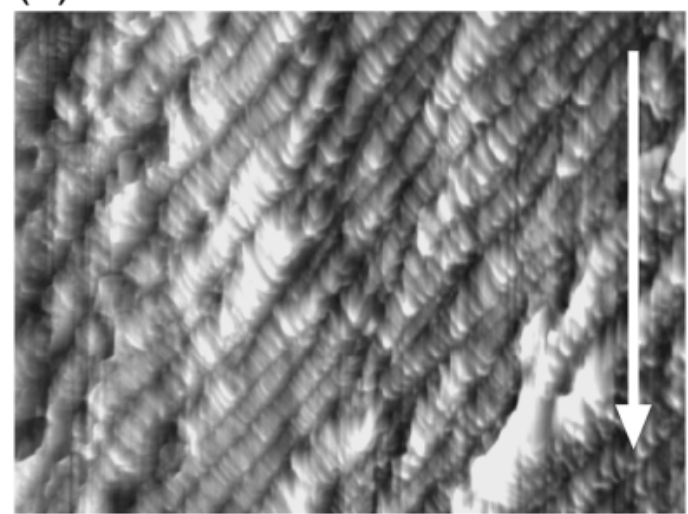

Crack direction

Fig. 3 Scanning electron micrograph of fatigue surface of A-specimen.

\section{(a) 0002 diffraction}

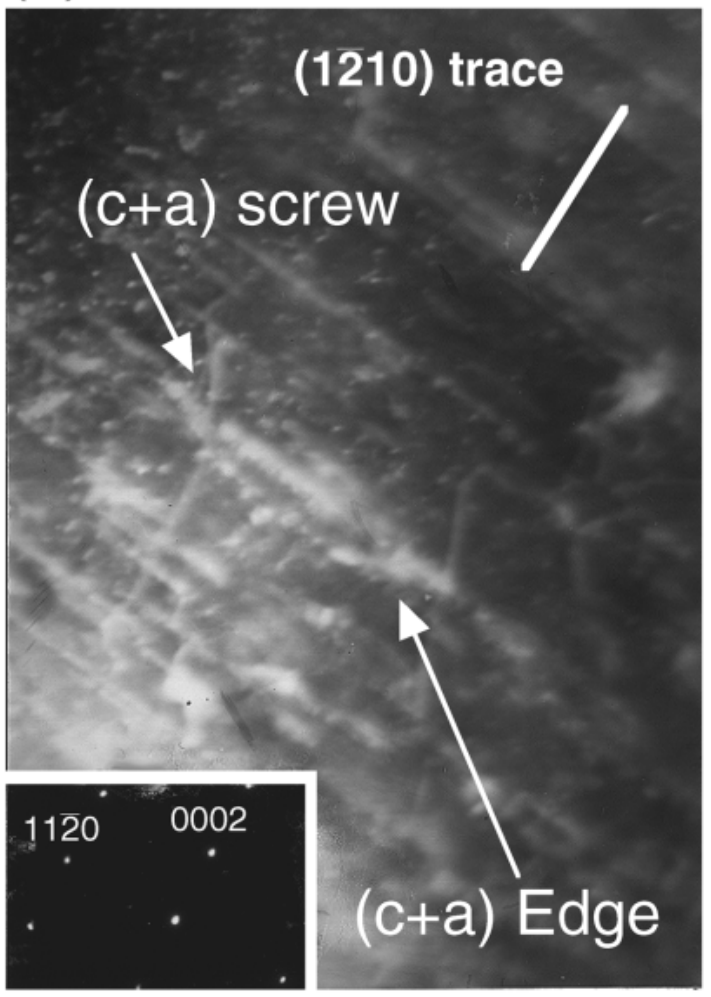

$\Delta K=1.5 \mathrm{MPam}^{1 / 2}$ (b) 1120 diffraction

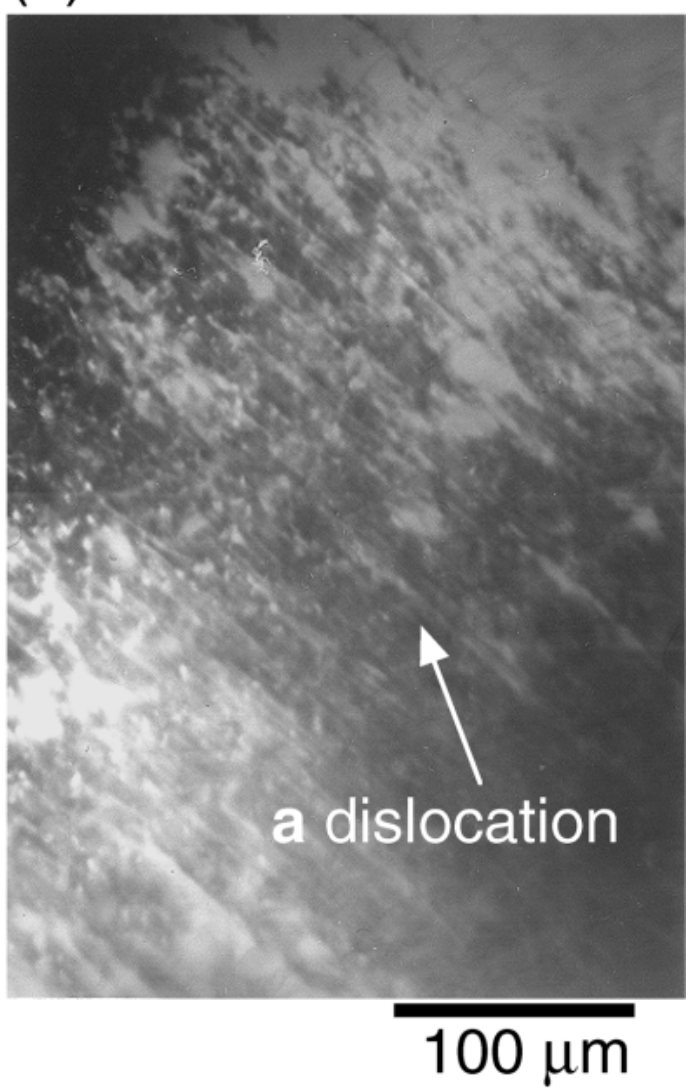

Fig. 4 Dislocation structure near crack surface of A-specimen.

た.

$\mathrm{F}$ 試料に抢けるき裂伝播経路は，前報5で述べたものと同 様に, 疲労き裂は切欠に対して平行に沿って伝播し, その周 囲には多くの $\{10 \overline{1} 2\}$ 双晶変形が生じていた.

Fig. 6 に各試料の疲労き裂進展速度 $d a / d N$ と $\Delta K$ の関係 を示す， $\Delta K_{\text {th }}$ は B 試料が約 $1.2 \mathrm{MPam}^{1 / 2}$ で最も高く, $\mathrm{F}$ 試 料が約 $0.55 \mathrm{MPam}^{1 / 2}$ で最も低い，また同一 $\Delta K$ で比較する と, $d a / d N$ は $\mathrm{F}$ 試料が速く, B 試料が最も遅くなってお り, 総じて $\mathrm{B}$ 試料の疲労き裂進展抵抗が最も高いといえ
る。ここで $\mathrm{D}$ 試料のプロットは，き裂が $[0001] に$ 進展した 範囲の值である. $\Delta K=0.5 \mathrm{MPam}^{1 / 2}$ では, 疲労き裂が進展 しなかったが，今回 $\Delta K \simeq 0.8 \mathrm{MPam}^{1 / 2}$ でき裂が進展したこ とから， $\mathrm{D}$ 試料の $\Delta K_{\mathrm{th}}$ はこの範囲であり， $\mathrm{F}$ 試料より高く $\mathrm{A}$ 試料とほぼ同程度であると推測される。また $\Delta K$ のわず かな増加により $d a / d N$ は急激に増加し, $\mathrm{F}$ 試料の值を越え ている. 前述のように, $\Delta K=0.9 \mathrm{MPam}^{1 / 2}$ 以上では, 別の き裂が発生し［0001]にき裂が伝播しなかったので詳細なこ とはまだわからないが，この方位の $d a / d N$ は，実際にはか 


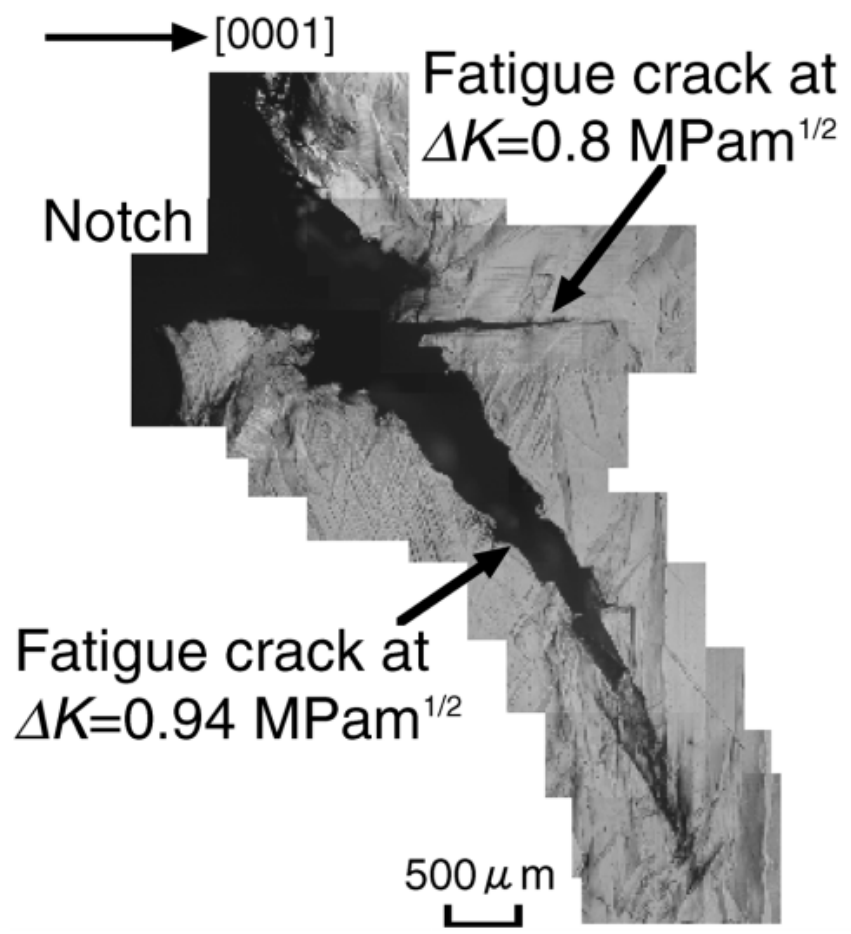

Fig. 5 Crack profile of $\mathrm{D}^{-}$-specimen.

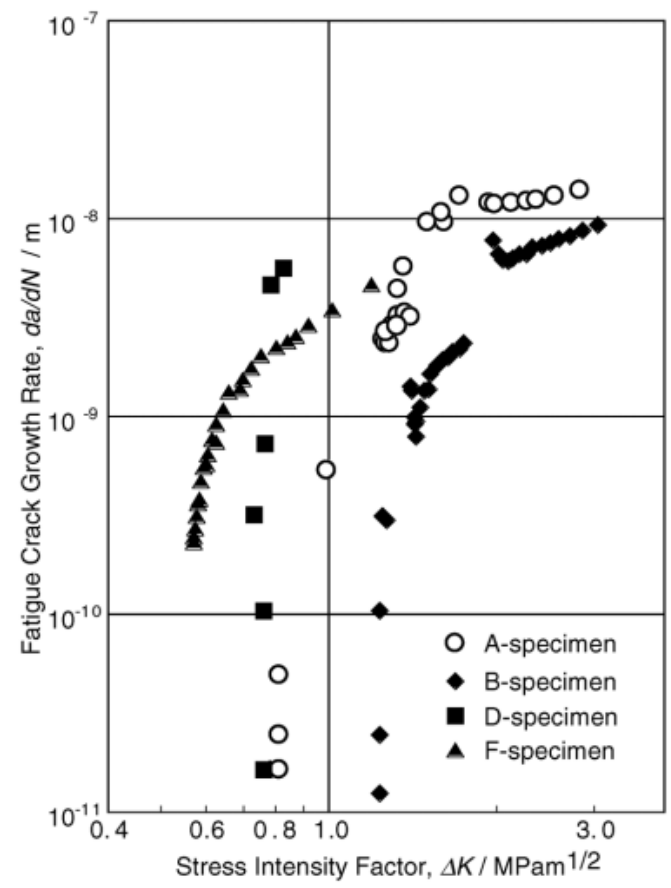

Fig. 6 Fatigue crack growth resistance curves of A-, B-, Dand $\mathrm{F}$ - specimens.

なり高い值を示す可能性がある。この $d a / d N$ の方位依存性 は, チタンでは3,4)，F試料が A, B 試料よりも高くなってい るが，マグネシウムでは全く逆の傾向になっている.

\section{4. 考察}

筆者らはこれまで，チタン単結晶の $\mathrm{A}$ 打よび $\mathrm{B}$ 試料で は，き裂は〈 $11 \overline{2} 0\rangle$ に伝播し，破面にはき裂伝播方向に対し (a) Lower $\Delta K$ region

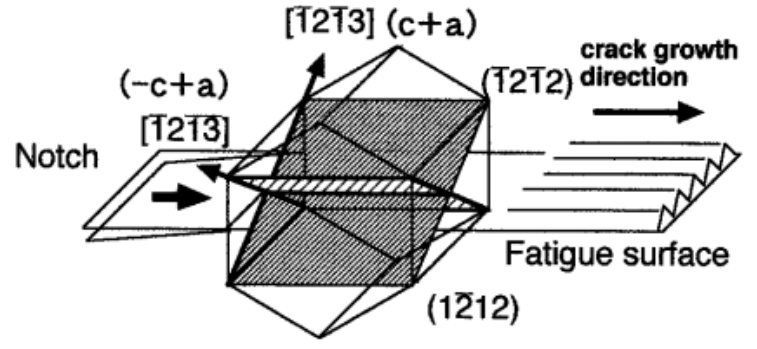

(b) Higher $\Delta K$ region

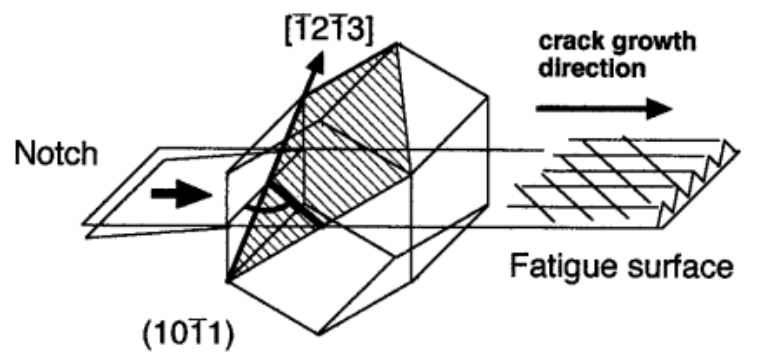

Fig. 7 Schematic illustrations of fatigue crack propagation mechanism in A-specimen.

垂直なストライエーション状模様が形成されることから，き 裂先端で 2 つ柱面すべりの slip-off によるき裂伝播モデル を提案した ${ }^{3-5)}$ 。しかしマグネシウム単結晶の場合, き裂伝 播方向は〈1010 0 であり，その破面形態はチタンとは全く異 なっている．また筆者らはマグネシウム単結晶の〈 $11 \overline{2} 0\rangle$ 引 張で活動するすべり系を調査してきたが6-8)，その場合，室 温では $\{11 \overline{2} 2\}<\overline{1} \overline{1} 23\rangle 2$ 次錐面すべりにより降伏し，柱面す べりはほとんど活動しない。さらに Fig. 4 のように, 破面 近傍には多くの $(\boldsymbol{c}+\boldsymbol{a})$ 転位があることから, マグネシウム の $\mathrm{A}$ 試料では $(\boldsymbol{c}+\boldsymbol{a})$ 錐面すべりを伴った疲労き裂進展であ るといえる．そこで Fig. 7 に示す疲労き裂進展モデルを考 えた. A 試料では, 切欠に対して 2 次錐面 $\{11 \overline{2} 2\}$ は Fig. 7 (a)のような方位関係にある. $\Delta K$ が低い場合，(12 12 打よ び $(1 \overline{2} 1 \overline{2})$ の 2 つの 2 次錐面でそれぞれ $(\boldsymbol{c}+\boldsymbol{a}),(-\boldsymbol{c}+\boldsymbol{a})$ 方 向に交互にすべりが生じ，いわゆるせん断型の変形が生じて き裂が進展する．この 2 次錐面の交線方向が $[10 \overline{1} 0]$ あ゙あ ために, き裂開口に伴い, 破面上に伝播方向に平行な筋模様 が形成され，き裂は $[10 \overline{1} 0]$ へ伝播すると考えられる， $\Delta K$ が 増加し，き裂近傍での応力が増加すると，この 2 次錐面す べりに加え $\{10 \overline{1} 1\}\langle 11 \overline{2} 3\rangle 1$ 次錐面すべり ${ }^{6)}$ も活動するよう になる. 1 次錐面は破面である $(11 \overline{2} 0)$ と約 $43^{\circ}$ で交差してお り，この 1 次錐面ですべりが生じることでき裂が開口すれ ば，Fig. 3(b)のき裂進展方向に対し $43^{\circ}$ の筋模様が形成され ると考えられる。 また Fig. 4(b)では多数の $\boldsymbol{a}$ 転位が観察さ れたが，A 試料では, 結晶方位関係から, $\boldsymbol{a}$ 転位を生じる底 面すべりは活動することができないので，これらの転位は直 接すべりにより形成されたものとは考えにくい，ここで上記 のモデルに扔いて, 2 つの 2 次錐面の交線上で 2 つの $(\boldsymbol{c}+\boldsymbol{a})$ 転位が ( 1 )式のような転位反応を生じた結果, 2 つの $\boldsymbol{a}$ 転位 を生じたと考えると, き裂進展により, 多数の $\boldsymbol{a}$ 転位が形 成されたことが説明できる. 


$$
(\boldsymbol{c}+\boldsymbol{a})+(-\boldsymbol{c}+\boldsymbol{a}) \longrightarrow 2 \boldsymbol{a}
$$

B 試料に抢いても, 切欠方向は異なるが, 疲労き裂進展方 向, および破面の形態は同じであることから, 同じき裂伝播 機構であると言える.

\section{5. 結}

\section{言}

マグネシウム単結晶を用いた疲労き裂進展試験の結果, 切 欠方位に依存して疲労き裂進展挙動は大きく異なった．その 結果をまとめると以下のようになる.

(1) 切欠面抢よび切欠方向が，それぞれ $(1 \overline{2} 10)$ および $[10 \overline{1} 0]$ (A 試料)，（1100)抢よび $[11 \overline{2} 0]$ (B 試料)の場合，き 裂は $(1 \overline{2} 10)$ に沿って $[10 \overline{1} 0]$ に進展した.

(2) 切欠面および切欠方向が $(1 \overline{2} 10)$ および $[0001]$ (D 試 料)の場合, $\Delta K=0.8 \mathrm{MPam}^{1 / 2}$ で $[0001]$ に疲労き裂が進展 し，それ以上では，底面に平行な方向へ偏向して進展した。

(3) 切欠面打よび切欠方向が (0001) 拈よび $[11 \overline{2} 0]$ (F 試
料)の場合, $\{10 \overline{1} 2\}$ 双晶を伴って疲労き裂が進展した.

(4) 疲労進展速度 $d a / d N$ と応力拡大係数範囲 $\Delta K$ の関係 を調査した結果, 疲労き裂進展抵抗は $\mathrm{F}$ 試料が最も低く, B 試料が最も高くなった。

\section{文献}

1) P. J. E. Forsyth: Acta Metall. 11(1963) 703-715.

2) Y. Mine, S. Ando, K. Takashima, H. Tonda and Y. Higo: J. Japan Inst. Metals 61 (1997) 41-48.

3) Y. Mine, S. Ando, K. Takashima, H. Tonda and Y. Higo: J. Japan Inst. Metals 62(1998) 708-717.

4) Y. Mine, T. Yamada, S. Ando, K. Takashima, H. Tonda, Y. Higo and P. Bowen: Key Engineering Materials 145-149 (1998) 721726.

5) S. Ando, N. Iwamoto, T. Hori and H. Tonda: J. Japan Inst. Metals 65 (2001) 187-190.

6) S. Ando, K. Nakamura, K. Takashima and H. Tonda: J. Japan Inst. Light Metals 42(1992) 765-771.

7) H. Tonda and S. Ando: Metall. Mater. Trans. A 33A (2002) 831836.

8) S. Ando and H. Tonda: Mater. Sci. Forum 350-351 (2000) 43-48. 